\title{
A.J. du Plessis
}

DIE BYBEL

\section{IN ONS DAAGLIKSE LEWENSPRAKTYK}

Omdat die konferensietema, sowel as hierdie spesifieke, onderwerp, in bepaalde terminologie uitgedruk word, is dit nodig dat $n$ spreker self sê wat hy daaronder verstaan.

\section{Terminologie}

„Die Bybel": In die aanduiding van die konferensietema word van „,die lewende Woord" gepraat. Daarmee word die Bybel as Woord van God, openbaring wat lig werp op alle sigbare en onsigbare dinge, maar ook as oproep tot die gemeenskap en die heil van God, gekarakteriseer. Deur die Bybel se inhoud roep God ons dus in ' $n$ werklikheid en op tot ' $n$ werklikheid wat ons nie ken en sien met die natuurlike verstand en oog nie. Volledige oorgawe aan hierdie Woord is dus voorvereiste. Eie voorveronderstellinge is taboe.

„ons daaglikse lewenspraktyk": In dié tema word ,praktyk" naas „,wetenskap" geplaas. Ek wil dit so aanvaar mits „daaglikse lewenspraktyk" nie as iets anders en iets minderwaardigs in vergelyking met die beoefening van sistematiese wetenskap gesien word nie. Myns insiens kom alle handelinge van die Christen in een en dieselfde lig van die openbaring te staan, kry dit sin en betekenis in een en dieselfde lig en moet dit daarvolgens beoordeel word. Hierdie lig wat die Bybel oor alle dinge laat val, baken die raamwerk vir ons af waarbinne Christene dink en doen, en kleur dit vir ons in met be lofte, appèl en gebod.

\section{Die Bybel in ons daaglikse lewenspraktyk - onmisbaar}

Dat die Bybel vir ons onmisbar is, hoef geen betoog nie. Dit gee immers geen formele kennis nie, maar dit is die Woord wat ons in gemeenskap met God bring (,woord van die geloof" - Rom. 10:8), wat diep indring en beoordeel, wat woord van die lewe is, wat wys maak tot saligheid, wat onderwys gee in die ware geregtigheid, wat leer deur die gebeure van die verlede, wat hoop gee... Vandaar die oproep: Laat die woord van (of „oor") Christus ryklik in julle midde 'n plek kry (Kol. 3:16).

Dit is wel nodig om in hierdie verband te waarsku teen die volgende voorkomende misbruike: opdringing van eie vrae en behoeftes aan die Skrif en 
gevolglike forsering van antwoorde, fragmentariese Skrifgebruik wat die geheel misken, die gebruik van die Skrif om eie denkkonstruksies van fundering te voorsien, miskenning van die skopus (doel) van die Skrif.

Ten einde in die lig van die Skrif te staan en te handel, moet die gelowiges intensief en met biddende harte met die Skrif omgaan, ja, as 't ware in sy Gees ingeweek word. 'n Ander wyse van gebruik met die oog op die lewensprakty $k$ is daar nie.

\section{Die lig van die Skrif op ons ,daaglikse lewenspraktyk"}

Alvorens ons kan weet wat ons daagliks moet en mag doen, en hoe ons dit moet doen, moet ons die lig van die Skrif soek oor die vraag wat ons daaglikse lewe is, in watter konteks dit afspeel.

3.1 Ons lewe in 'n wêreld wat God se skepping is en as sodanig nie deur Hom losgelaat is nie. Hy sorg nog vir alles en almal. God werk nog sy bedoeling met en in sy skepping uit. Andersyds is hierdie wêreld deur die sonde aan die nietigheid onderwerpe, ingedompel in die verganklikheid, onvry. Die Satan is ook owerste van hierdie wêreld en behou dit nog as operasieveld tot die jongste dag. Die skema van hierdie kosmos, alles wat tot die leefwyse en strukture van hierdie wêreld behoort, gaan verby. Geen beskouing oor die empiriese menslike bestaan en sy vorme mag bloot van die skepping uitgaan en daaruit die blywendheid daarvan aflei nie.

3.2 Ons daaglikse lewe word geleef tussen koms en koms. Die koninkryk het gekom - „reeds"; andersyds het die ryk nog nie in sy heerlikheid gekom nie - „nog nie". Die feite gee ' $n$ besondere dubbelsinnigheid aan die teenwoordige wêreld en die lewe daarin: Christus heers, maar Hy heers te midde van sy vyande. Die beslissende oorwinning is behaal maar die resultate daarvan, naamlik ons volkome verlossing, is nog saak van toekoms. Die lewe van die , elowiges word dus geleef, om so te sê, tussen die twee pole van Christus se koms in die vlees en sy koms in heerlikheid.

3.3 Dit beteken dat die nag nog voortduur, en so ook die werke van die duisternis; terselfdertyd het die daeraad van die heil aangebreek en begin die kinders van God reeds in die lig lewe terwyl die skema van die ou, teenwoordige bose wêreld nog bly voortbestaan. Die nuwe lewe wat die gelowiges nou reeds mag lewe, is reeds die toekoms wat in die hede verwerklik begin word. Ons lewe dus in $h$ swaargelade eskatologiese spanning. Die tyd is kort. Christus kom gou. God het so beslissend op die bestaan en vorm van hierdie wêreld ingegryp dat dit op plofpunt staan voordat die heerlikheid van die toe koms intree.

3.4 Waarom bestaan die teenwoordige wêreld nog? By die antwoorl op hier- 
die vraag gaan die paaie, ook onder Christene, uiteen. Vir sommige is dit die tyd van ontplooiing, ontsluiting van die skepping, ensovoorts - alles wat in Christus moontlik sou word. Myns insiens lê die Skrif daarop geen klem nie. Dit is die tyd wat primêr sy betekenis ontleen aan die feit dat die evangelie van die koninkryk aan alle nasies verkondig moet word. Daarom is dit die tyd van God se geduld en verdraagsaamheid. Met die oog op die versameling van sy volk, wat die nuwe aarde sal beërwe, behou God die menselewe met sy ordeninge. Die wêreld is saailand waar Christus in die skynbaar swak gestalte van die saaier teenwoordig is, onder baie weerstande.

\section{Die lig van die Skrif op ons praktiese lewe in die teenwoordige wêreld}

In punt 3 het ek enigsins (onvolledig!) 'n perspektief probeer gee. As ons die Skrif volg, sal ons merk dat ons lewe binne hierdie perspektief beskryf word en geleef moet word.

4.1 Vanuit die perspektief dat die koninkryk reeds gekom het, kan ons lewe hier en nou reeds tot openbaring kom as lewe volgens die nuwe skepping. Die gelowiges behoort alreeds tot die nuwe skepping. Ons het oorgegaan uit die dood in die lewe. Dit is ons unieke posisie: ons lewe nog in die ou wếreld maar as mense wat tot die nuwe skepping behoort. Die nuwe skepping neem voor alles gestalte aan in die lewe van mense. Die herskepping van alle dinge volg die herskepping van die mens. Hierdie nuwe lewe is om te lewe op die rand van die voleinding. Twee aspekte vloei hieruit voort:

4.1.1 Ons moet lewe in algehele heiliging en toewyding aan God en sy diens. Ons is gekoop as eiendom. Christus en sy Gees regeer oor ons hele lewe en al ons handelinge. Rom. 12:1 e.v. stel dit miskien die helderste: ons liggame (dit wil sê ons totale funksionaliteit in sy verskeidenheid) moet soos 'n heilige offerande aan God gewy word. Hierdie heiliging kan op verskillende wyses onder woorde gebring word: doen alles tot eer van (of vir) die Here, lewe in goeie werke, doen alles in die Nam van Jesus Christus, voor die aangesig van God. Daarom is die gelowiges steeds besig om te beproef (vas te stel) wat die goeie en welgevallige en volmaakte wil van God is. Dit kan nie geskied deur die formele nakoming van gebooie nie. Die wil van God, alhoewel as riglyne in die Skrif geopenbaar, kan alleen situatief toegepas word en verstaan word langs die weg van geloofsgemeenskap deur die Gees. Die swaartepunt en samevatting van die heiliging is die liefde, tot God, tot die broeders en tot die naaste.

4.1.2 Behalwe tot heiliging het God ons ook tot uryheid geroep. Dit beteken vryheid van die oorheersing van die Satan en die vlees om vir God te lewe. Dit beteken ook dat ons in vryheid kan gebruik maak van alles wat God aan 
mense in hierdie wêreld wil uitdeel. Alles is rein vir die reines. Ons kan deelneem aan die hele lewe: arbeid, koop en verkoop, speel, ete en drinke, huwelik en gesinslewe, kulturele lewe. Die vryheid word egter bepaal deur die liefde en diens. Ook die vryheid om te mag geniet en deel te neem, moet in die gebed beoefen word. „Alles behoort aan julle, maar julle behoort aan Christus" - daarin lê die verband van vryheid en heiliging opgesluit.

4.2 Ons lewe ook onder die gesigspunt van die koninkryk wat nog nie gekom het nie. Die ou wêreld waarin die kragte van die Bose werk, bly nog voorlopig voortbestaan. Dié feit bring 'n swaar spanning mee. Paulus verwoord dit: die wat vroue het, moet wees asof hulle nie het nie ... die wat koop asof hulle nie besit nie, die wat die wêreld gebruik asof hulle dit nie ten volle gebruik nie; want die gedaante van hierdie wêreld gaan .verby (I Kor. 7). Hierdie wêreld soos ons hom ken, is 'n verbygaande wêreld. Daarom mag ons dit nie beleef en gebruik asof dit blywend is nie. Dit geld ook van al die sogenaamde "terreine van die lewe". Hierdie wêreld bied geen blywende tuiste nie, en God omvorm ook nie somaar die bekende dinge van die aarde om dit nuwe skepping te mak nie. Allermins geskied dit langs die weg van ontwikkeling. Daarom:

4.2.1 Ons is vreemdelinge in die teenswoordige wêreld. Calvyn sê dat ons ' $n$ natuurlike neiging het tot 'n beesagtige liefde vir hierdie wêreld. Ons lewe binne die vorme en verbande van hierdie wêreld vertoon 'n gestrektheid na die toekoms. Dis veral die Gees wat die verlange na die volmakte wek en in stand hou.

4.2.2 Die gelowige bewaar dus ook 'n sekere distansie wat op verskeie wyses tot uitdrukking kom. Ons gaan nie op in die goed van die aarde en die be. drywigheid van die mens nie. Ons werk nie of ons lewe daarvan afhang nie, ons is nie getroud asof dit die hoogste is nie. In die lig van die toekoms word alles van hierdic aarde gerelativeer.

1.2.3 Ons lewe verloop in stryd en waaksaamheid. Ons lewe onder bedreiging. Oral bou die Satan trone. Ons is nie besig om rustig die lande te saai en te ploeg, wagtend op 'n pragtige resultaat uit ons werk nie. Ons bly nét staan in die geveg, en dan net omdat ons die volle wapenrusting wat God verleen, neem. Ons moet volhard, ons taak is, vanuit hierdie gesigspunt beskou, om ook vir Christus te ly.

4.3 Vreemdelingskap beteken egter nie afsydigheid van die vorme en bedrywigheid wat behoort by hierdie teenwoordige wêreld nie. As ons die menslike lewe sou vermy, sou ons die feit misken dat God nou nog alle dinge onderhou en regeer tot die bestemming wat hy daarvoor het. Christus het ook die wêreld liefgehad, en sy roepstem weerklink op hierdie wêreld. God werk op die terrein van hierdie wêreld. 
4.3.1 Elkeen moet dus in die gewone lewe waar die menslike krag en arbeid ontplooi, sy plek inneem. Aan elkeen het die Here sy eie soort van lewe as 'n wagpos toegeken (Calvyn). Elkeen moet in sy eie omstandighede voor God lewe, die Here en die naaste dien. Sodoende sal ons lewe nie sonder bestemdheid verloop nie.

4.3.2 Op die pos waar die Here elkeen geplaas het, moet ons lig van dic wêreld wees deur die eiesoortige wyse waarop ons God en die naaste daar dien, hetsy as man, vrou, amptenaar, ouer, owerheidspersoon.

4.3.3 Al kan ons die gebroke lewe nie heel nie, kan ons die kwaad enigsins weer en teëhou, die sout wees wat die bederf teèhou.

4.3.4 Ons kan die taak van die gelowiges in die gewone lewe verder spesifiseer as ,dit wat goed en nuttig is vir die mense". In alle posisies wat ons beklee, doen volop geleentheid voor om in liefde die welsyn van mense te dien. Mense ly deur siekte, onreg, armoede, vernedering. Oral waar pyn is van watter aard ook al werk die gelowige mee. Op sosiale en politieke terrein is hier 'n geweldige taak in 'n geplunderde menselewe.

4.3.5 Ons arbeid en diens in die wêreld staan ook sterk in die lig van die tussentyd as tyd van die versameling, die missio Dei. Alle gelowiges is opgeneem in die groot sending. Elkeen moet deur woord en lewenswandel lig van die wêreld wees. Die Skrif waarsku telkens dat niks gedoen mag word wat die teëstanders geleentheid gee om te laster nie, of wat dié wat buite is (ongelowig is) ontmoedig nie. Maar ook ten opsigte van ons arbeid binne die strukture van hierdie wêreld is die missionêre doelwit baie belangrik. Ons sai ons beywer daarvoor dat die swak middel van owerheidswette gebruik word as dit die ergste vergruweliking en ontmensliking kan keer. Want ons wil die menselewe as saailand soveel moontlik help behou. Vir dieselfde doel sal ons 'n menselewe van reg en orde soek, want dit kan beter saailand wees as lewe van wanorde en haat. "Wat help dit om die menselewe as saailand van God te dien?", is 'n vername vraag in ons handeling as Christene.

\section{Saamgevat}

Die Skrif open vir ons perspektief op die alledaagse lewe waarin ons staan. Hierdie lewe mag ons nie ontvlug nie maar ook nie daarin opgaan nie. Binne die konteks van God se doel om vir Hom 'n volk te versamel wat ywerig in goeie werke is - nou reeds - , en wat erfgename van die nuwe aarde kan word, word vir ons ' $n$ groot taak ontplooi. Maar nooit om die ryk te laat kom nie of te bou nie, maar om dit te verkondig, te weerspieèl en af te wag. 